\title{
AINDA A ORIGEM E INTRODUÇÃO DA APELAÇÃO NO DIREITO LUSITANO
}

\author{
Luiz Carlos de Azevedo \\ Professor Associado do Departamento de Direito Processual da \\ Faculdade de Direito da USP
}

Resumo:

No final dos anos 70, durante o exílio do Professor Marcello Caetano no Brasil, tivemos ocasição de estabelecer agradável e proficuo convívio com o ilustre mestre, situando nossos diálogos, mais amiúde, na história das instituições jurídicas lusitanas e nos reflexos que estas proporcionaram ao Direito pátrio.

Porque as fontes não esclareciam quanto à data precisa em que a primeira lei sobre a apelação fora editada em Portugal, perguntamos, certa feita, em meio a almoço ensolarado na orla da Guanabara, o que pensava ele a respeito: se isto ocorrera nas Cortes de Leiria, em 1254; ou nas de Coimbra, sete anos mais tarde; ou ainda, no entremeio de uma e outra?

Não nos replicou de pronto o mestre, pois o tema demandava fôlego, preferindo deixá-lo para outro dia ou para correspondência futura. Colheu-o a morte, todavia, e só fomos conhecer a sua resposta, quando da publicação de sua obra póstuma, História do Direito Português, na qual os estudos que anteriormente houveramos realizados sobre essa matéria são por ele comentados no capítulo apropriado.

Mais como uma homenagem ao historiador, jurista e professor, esboçamos estas linhas complementares em torno do tema, abordando, preliminarmente, as condições sócio-jurídicas em que viviam e agiam os súditos do recém-formado reino lusitano; as condições em que, mais tarde, em razão das idéias desenvolvidas nas Universidades, passam a ser aplicados vários institutos provenientes do Direito Romano; e, finalmente, o momento em que teria sido determinado, como regra legal, nos moldes da antiga appellatio, o recurso de apelação em Portugal.

Abstract:

At the end of the seventy years, during the exile of Professor Marcello Caetano in Brazil, we have the occasion to establish a delightful and profitable conviviality with the illustrious master, placing our dialogues, mainly, on the history of the Lusitanian juridical institutions history and on reflexes those have proportionated on the national right.

Because the sources could not clarify as for the accurate date in which the first law upon appeal was enacted in Portugal, we have asked, once, in a sunny dinner at the Guanabara coast, what the think about this: should this has occurred at the Leiria Courts on 1254 , or at those of Coimbra, seven years later, or further, in the middle of one and another? 
The master has no immediately answered, because the theme needs vitality, choosing to have left it to another day or to future correspondence. The death have, however, collected him, and we will know the answer only when his posthumous work were published, the History of the Portuguese Right (História do Direito Português), in which the studies that formerly we have performed about this subject-matter are commented by him on the appropriate chapter.

More as homage to the historian, jurist and professor, we draft these complementary lines about the theme, preliminarily approaching the socio-juridical conditions in which have lived and acted the subjects of the newly-formed Lusitanian Kingdom; the condition in which, later on, in reason of the ideas developed at Universities, were applied to several institutes arising out from the Roman Right; and, finally, the moment in which would be determinated, as legal rule, under the patterns of the ancient appellatio, the appeal resource in Portugal.

1. Em 1976, quando da publicação do trabalho que ora se reexamina, disseramos que "se valem os documentos para a fixação e precisão cronológica dos fatos, o atestado comprobatório da apelação no-Direito português, está na lei de D. Afonso III, passada nas cortes de Leiria - 1254, quando, por primeiro, o povo se faz representar ou de Coimbra - 1261 - constando do Livro das Leis e Posturas", no original, fls. 27, verso, $2^{\mathrm{a}}$ coluna e 28, $1^{\mathrm{a}}$ coluna; na Portugalia Monumenta História, "Leges et Consuetudines", com as variantes, p. 247; e na edição impressa da Faculdade de Direito de Lisboa, de 1971, p. 95. (Luiz Carlos de Azevedo, Origem e Introdução da Apelação no Direito Lusitano, S. Paulo, FIEO, 1976, p. 104).

Logo a seguir, na mesma obra, acrescentávamos: "Importante ressaltar a frase, apele logo, ca tal quero que seia custume de meu Reyno"; se o rei dizia querer ser costume de seu reino, é porque até aquele momento, ainda não o era; no mesmo Livro das Leis e Posturas, repete-se a lei, mas, agora, naquela se diz: "ca tal he e quero que seia custume do meu Reyno"; deduz-se de tais expressões que o rei, por primeiro, introduz a possibilidade de apelar e, nos editos subseqüentes, insiste na aplicação da medida, frente à oposição dos que the eram contrários" (p. 105).

Colocando-se em posição divergente, o Professor Marcello Caetano faz as seguintes observações: "O Dr. Carlos de Azevedo deduz dos primeiros textos que se trata de inovação, porque se o rei quer que dai por diante seja o costume, isso mostra não ser a norma usada até aí. Afigura-se que a fórmula exata é a que conta da segunda versão da L.L.P. "porque tal é e quero que seja costume" Na verdade, é que 
na época faz sentido, representando a confirmação legal de um costume. Não teria lógica que o rei quisesse criar um costume por lei. A norma ou é legal ou consuetudinária. O que era freqüente era consagrar um costume por lei, o que dava autoridade à regra legislada e consolidava uma prática, generalizando-a" (História do Direito Português, Lisboa, 1981, Verbo, p. 406)

Duas páginas atrás, refere-se o mestre a outro texto, contido também no Livro das Leis e Posturas, estabelecendo que este (no original, fls. $6 \mathrm{v} ; 2^{\mathrm{a}}$ coluna, até fls. $13 \mathrm{v} ; 1^{a}$ coluna; na edição impressa, p. 29 a 50) não se trata de um "decreto dimanado da vontade régia" Seria, isto sim, "mero capítulo de um pequeno tratado do novo processo adotado no tribunal da corte" e cujos conceitos "teriam sido seguidos a preceito durante muito tempo, pois como lei vieram a ser recolhidos nas Ordenações Afonsinas". ( Ob. cit., p. 403-4) (nas Ordenações Afonsinas, Liv. III, Tít. 71)

Em nota, menciona Marcello Caetano que nós havíamos considerado o texto em apreço como lei, "passada nas Cortes de Leiria, de 1254 - ou de Coimbra, 1261 ", mas, como já ficou dito acima, a lei a qual nos referidos como introdutória da apelação vem em outras passagens do Livro das Leis e Posturas, e não nessa. Por outro lado, a lei a qual nos referimos é indiscutivelmente lei, tanto que o próprio mestre como lei a reconhece.

2. Esclarecidos estes pontos preliminares, cumpre-nos examinar, agora, alguns aspectos de extrema relevância para a melhor compreensão da complexa situação sócio-jurídica que envolvia os empreendedores da reconquista do solo ibérico frente ao invasor muçulmano, a fim de ressaltar, a seguir, as modificações profundas ocorrentes após a introdução do Direito Romano na legislação dos reinos cristãos; caber-nos-á demorar, com desejado esmero, no estudo da instituição das cortes, acentuando a importância que estas conheceram como elemento vivo e eficaz para a solução dos problemas mais prementes que interessavam aos habitantes daquelas regiões, e que diziam respeito, entre outros, com a guerra e a paz, com a elaboração de leis que regulassem as suas condutas, com a fixação e com a quebra da moeda, com a imposição de tributos. A final, cuidaremos de remontar ao tema da origem e introdução da apelação, pretendendo deixar assentado que esta, resultante de instituto oriundo do Direito Romano, em nada se afinava com as queixas ou querimas do período antecedente, nem com outras modalidades de remédios, precária ou eventualmente utilizados até o seu advento. 
3. Não há como confundir costume e lei. Mesmo na Idade Média, onde se depara com certa imprecisão de termos e conceitos, mormente em sede jurídica, por costume se entende aquele "conjunto de usos nascidos de fatos concretos, que retiram a sua autoridade do tempo, que o consagra: sua dinâmica é a da tradição: um dado, mas um dado vivo, não estagnado, sempre passível de evolução, sem nunca ser submetido a uma vontade popular" (Régine Pernoud, Idade Média, o que não nos ensinaram, Rio de Janeiro, 1979, Agir, p. 54)

Acontece, todavia, que a partir do século XIII, muitos costumes passam a ser reduzidos por escritos, por determinação real; mais, ainda: por força deste processo que gradativamente se desenvolve, os costumes são alterados, seja no sentido de serem aplicados não mais regionalmente, mas em todo o reino; seja no sentido da romanização, por força da mencionada recepção, proveniente das idéias ensinadas e propagadas nas universidades européias.

Pode-se afirmar, então, que a expressão costume, nessa etapa de transição, aparece significando tanto o hábito resultante do uso alongado no tempo, quanto uma disposição emanada da autoridade; e, nesta segunda hipótese, confirmado ou modificado de acordo com a conveniência do governante, aquilo que era costume, acaba se transmudando em lei. (a respeito, John Gilissen, Introdução Histórica ao Direito, Lisboa, 1979, Fundação Calouste Gulbenkian; José Manuel Perez-Prendes y Munõz de Arracó, Curso de Historia del Derecho Español, Madri, 1978, Ed. Darro, p. 390; Alfonso Garcia Gallo, El origen y la evolución del Derecho, Manual de Historia del Derecho Español, I, Madri, 1975, p. 369)

Evidentemente, um ato de tal ordem, de alcance geral, sofre resistência por parte dos senhores da nobreza e do clero, que não pretendem se despojar de suas imunidades e privilégios; e nem sempre é aceito facilmente pelos comunheiros, arraigados que estão aos hábitos peculiares às regiões em que residem. Mas, ainda que as novas regras possam abalar a estrutura tradicional da sociedade para a qual se dirigem, vêm elas justificadas na política de que é preciso oferecer "aos povos uma justiça mais reta, mais objetiva, menos sujeita ao jogo das influências ou da venalidade". Embora verdadeira, esta assertiva ocultava outra, "a vontade do rei de meter pé dentro da administração municipal, na linha da evolução da política de centralização do poder, que as próprias idéias romanísticas favoreciam" (Guilherme Braga da Cruz, O Direito Subsidiário na História do Direito Português, Coimbra, 1975, Faculdade de Letras da Universidade de Lisboa, p. 193, nota 20; a respeito, 
também, Nuno J. Espinosa Gomes da Silva, História do Direito Português, 1985, Fundação Calouste Gulbenkian, p. 168)

Árduo foi o caminho experimentado para a imposição da vontade real e para que prevalecesse, efetivamente, a ordem de que só o "Emperador, o rey puede fazer leyes sobre las gentes de su señorio e otro ninguno no ha poder delas fazer..." ("Las Siete partidas", I, 1, XII, "quien ha poder fazer leyes") Deste lavor imenso, não poderia o rei desaviar-se sem o concurso de terceiros: de seus letrados, conselheiros, sobrejuízes; além destes, outros ainda, chamados para compor as cortes, fossem nobres, prelados ou representantes dos concelhos sediados em seus reinos. "El monarca estaba obligado a buscar el consejo de hombres buenos inteligentes y sabios y con experiencia juridica antes de enmendar, abolir o ampliar la ley, pues el derecho" noble cosa es et buena quanto mas acordado es et mas entendido" (Joseph F. O' Allaghan, Las Cortes de Castilla y León, 1188-1350, Valladolid, 1989, Ambito, p. 128, citando, a final, ao texto das Sete Partidas, I, 1, 17/19)

Daí o importante papel que desempenharam as cortes na Península Ibérica, em época que, a par da beligerância permanente, tônica da reconquista e dos constantes desentendimentos entre os detentores do poder, nos reinos neovisigóticos, sobrava, também, este embate surdo, calcado no firme propósito que dos reis partia, no sentido de estenderem o seu comando sobre os senhorios locais; de sobreporem a justiça delegada diretamente pelo monarca à justiça dos concelhos; de imporem a lei geral aos foros e costumes regionais.

4. A intervenção da Santa Sé nos assuntos do reino determina o retorno do conde de Bolonha a Lisboa, primeiro, como "visitador, curador $e$ defensor"; falecido o irmão Sancho II, Afonso III é coroado rei de Portugal.

Para mais de dois anos atrás, o novo soberano havia firmado em Paris o juramento de colocar no reino "juízes justos e tementes de Deus", que se elegeriam "ou por votos do povo ou de outro modo lícito, conforme a lei de Deus" (Juramento do infante D. Afonso, inserto na bula de Inocêncio III, cartório da Sé de Braga, reproduzido por Frei Antonio Brandão, nas Crónicas de D. Sancho II e D. Afonso III, Porto, 1946, Liv. Civilização Editora, p. 96-99). Este outro modo lícito seria a nomeação e delegação dos juízes de fora parte, que se incumbiriam de estender a jurisdição real com vistas à consolidação deste poder sobre a autoridades dos ricos-homens, ricas-donas, mestres e priores de ordens, cavaleiros e todos aqueles que os tivessem nas suas vilas, castelos e herdades. 
Além desta providência, a imposição de leis civis sobre os foros eclesiásticos, as restrições às honras e imunidades dos nobres e as inquirições e confirmações régias iriam fornecer o curso para que a administração se centralizasse nas mãos da Coroa.

Em toda esta evolução, serve-se o rei do instituto já antes aludido, o qual será de grande relevo no correr dos séculos XIII e XIV, dada a incidência com que se sucede e em razão das conseqüências que acarreta: é a Cúria Régia, que se amplia para a Cúria Plena e que traz, também, a denominação vulgar de Corte (de cohors, cohortis, pátio, e daí, lugar de reunião), para onde acorrem oficiais palatinos, legistas e letrados a serviço do rei, seus vassalos mais chegados no exercício das funções civis e militares; ao lado destes, compõem a assembléia outros ricoshomens, mais os representantes do clero; e, por fim, os delegados dos concelhos.

Por aí se vê que o monarca não age sozinho; nas suas decisões, e ainda que isto pareça de certo modo contraditório, pois com elas está alcançando privilégios dos membros provenientes deste mesmos estamentos sociais, vale-se o rei da presença da nobreza e do clero para que conheçam respaldo. A partir de 1254, conta ele, também, com o concurso dos delegados dos concelhos das cidades e vilas de Portugal.

No tocante às Cortes de Leiria, de 1254, o Professor Marcello Caetano subestima o caráter parlamentar das sessões realizadas, considerando que "no intervalo das audiências públicas é que se trataria dos assuntos mais delicados" Assim, a participação teria tido mais o sentido de referendo, mesmo porque faltavam oradores eloqüentes, bem como a consciência de solidariedade entre os membros das classes presentes, não dispondo os burgueses, também, de condições para, à vontade, erguerem as suas vozes durante as audiências. (As Cortes de Leiria de 1254, Lisboa, 1964, Academia Portuguesa de História, p. 26-27)

Certo é, no entanto, que a partir desse momento, "a admissão dos homens bons dos concelhos..." "...não mais deixará de se verificar" (Marcello Caetano, Cortes, cit., p. 47). Aliás, a presença do terceiro estamento já era comum nos reinos vizinhos de Castela e Leão, nos quais está comprovada a presença destes cidadãos nas cortes reunidas no final do século XII e princípios do XIII. (Joseph F. O'Callaghan, ob. cit., p. 28; Claudio Sanchez Albornoz, La Curia Regia Portuguesa, siglos XII y XIII, in Investigaciones y documentos sobre las instituciones hipanas, Santiago, 1970, p. 395-6; Evelyn S. Procter, Curia y Cortes en Castilla y León, (1072-1295) Madri, 1988, Ed. Cátedra, p. 73) 
Quanto a esta participação popular, há dois aspectos significativos, que merecem análise: em primeiro lugar, não se está em tempos da monarquia absoluta, onde protocolo e pompa irão distanciar os membros de cada estado. Como bem acentuou Régine Pernoud em outra passagem de seus estudos históricos, a divisão em três classes aplica-se aos séculos XVII e XVIII, sendo superficial no que concerne à Idade Média; pode explicar o grupo, a repartição, a distribuição de força, mas nada revela no que diz respeito à origem, à força, à estrutura em profundidade desse tipo de sociedade. (Lumière du Moyen-Age: l'organisation sociale, Paris, 1981, Grasset, p. 13)

Ademais, quando se trata da Penísula Ibérica, verifica-se que todas estas pessoas, por força da reconquista, estavam combatendo lado a lado contra o inimigo comum, circunstância que os estreitava em idêntico e único intuito, arredando as naturais diferenças de origem, fortuna e condição.

O próprio local onde se reuniam as cortes permitia maior comunicação entre os presentes, entre os quais se incluíam o próprio rei, seus assessores diretos, vassalos da nobreza, clérigos, cavaleiros-vilãos, homens bons dos concelhos: não se espalhavam por palácio ou amplas galerias, mas se comprimiam numa das salas do castelo, mais apto à defesa do que ao fausto; uma simples visita aos remanescentes destas fortificações possibilita visualizar a singeleza do local em que se desenrolavam tais assembléias.

Já se disse, em outra oportunidade, que embora persistissem privilégios e imunidade, não se pode aceitar a existência de um feudalismo puro nos reinos ibéricos, no mesmo molde como é encontrado nas demais regiões da Europa. (Origem e Introdução, cit., p. 68) Por essa razão, em Castela, Leão e Portugal, os delegados das cidades, justamente porque estavam colaborando decisivamente para o assentamento dos territórios reconquistados, guardando-os contra a eventual reação dos árabes, "Ilegaran a figurar como elemento basico entre los constituyentes de la sociedad peninsular" (Claudio Sanchez-Albornoz, ob. cit., p. 439)

$\mathrm{Na}$ verdade, mais do que nunca, contava o rei com as cidades como elemento fundamental para compor a estrutura administrativa de seu governo, pois era delas que hauria homens válidos para formar suas milícias; como era delas que recebia o estipêndio para sustentar seus intentos.

Assim, não é possível excluir a função que desempenharam estes representantes junto às cortes, nos vários assuntos que ali eram tratados, pois nas 
suas vozes vinha o reforço de que o rei precisava para impor e insistir nas suas determinações. Comentando deliberação régia que tabelou gêneros e mercadorias, (Carta de 26 de dezembro de 1253, anterior, assim, às Cortes de Leiria) o Professor Marcello Caetano afirma que, nesse caso, para fazer a lei, o rei ouviu, além de seus conselheiros e ministros, os mercadores e homens bons dos conselhos do reino. (Subsídios para a História das Cortes Medievais Portuguesas, in Atas do Congresso Histórico de Portugal Medievo, Braga, 1963, v. XIV-XV. tomo I, p. 141). No mesmo teor, Antonio Sardinha, no prefácio que fez às Memórias e alguns documentos para a História e Teoria das Cortes Gerais, do Segundo Visconde de Santarém: é no apoio das camadas rudes e obscuras dos municípios que a Realeza se engrandece e radica. (Lisboa, 1924, Imprensa de Portugal-Brasil, p. LXXI)

Na própria tarefa de substituição dos costumes tidos por desajustados à nova política administrativa e jurisdicional, embora na sua maior parte, provenha ela da iniciativa régia, sob conselho prévio dos letrados, em outras vezes, se observa que resultava, também, da instância popular. É o que esclarece Gama Barros, ao reconhecer que "não raro acontece partir até dos povos a iniciativa para que o Direito Romano substituisse o direito estabelecido" (Histórias da Administração Pública em Portugal, Lisboa, 1945, Livraria Sá da Costa, Editora, v. I, p. 123)

Que o braço popular vai ganhando prestígio de forma gradual nas cortes, dão-nos conta os documentos relativos, ainda, à casa de Borgonha. Assim, por exemplo, o art. $42^{\circ}$ das Cortes de Santarém, com D. Afonso IV reinante, ano de 1331: "Outrosij senhor pedem vos os vosos poboos alguas cousas geraaes que son a boom vereamento da vossa terra e a prol comunal de todos..." (Cortes Portuguesas, Reinado de D. Afonso IV, Lisboa, 1982, Instituto Nacional de Investigação Científica, p. 42). $\mathrm{O}$ art. $1^{\circ}$ das Cortes de Lisboa, sob a Coroa de D. Fernando: “...que daqui en deante non fezesemos guerra nem moeda nem outros autos nenhuns de que se posa seguir dapno a nosa terra salvo com conselho dos nosos cidadaãos e naturaaes..." (Cortes Portuguesas, Reinado de D. Fernando I, Lisboa, 1990, Instituto Nacional de Investigação Científica, Universidade de Lisboa, p. 16)

Firma-se com tais providências uma das principais funções destas assembléias, qual seja a de "permitir aos povos formular as suas queixas para os reis repararem agravos e prevenirem a sua prática por meio de leis convenientes. $E$ essas leis deviam ser observadas, tendo os monarcas o cuidado de não transgredirem as resoluções tomadas em cortes ao resolverem depois casos 
concretos: quer dizer que essas leis formavam a legalidade a observar na administração corrente" (Marcello Caetano, Subsídios..., cit., p. 151.)

Idêntica tendência se manifesta nos reinos vizinhos, nos quais a maioria dos ordenamentos promulgados pelo rei nas cortes era uma resposta às denúncias e abusos ocorridos e às petições ofertadas por qualquer representante da nobreza, clero ou dos concelhos. Assim, por exemplo, as determinações de Sancho IV, de Castela, editadas nas Cortes de Palência, Haro e Valladolid, (1286, 1288 e 1293) atenderam a várias reclamações trazidas pelo povo. (Joseph F. O'Callaghan, ob. cit., p. 136-7)

Finalmente, já ao tempo de D. João I afirma Coelho da Rocha que leis, subsídios e negócios de importância eram tratados e decididos em cortes, as quais se convocaram pelo menos vinte e duas vezes. "Seus sucessores, até D. João II, imitaram-no. Foi a época das Cortes; e podemos dizer, a da grandeza de Portugal" (Ensaio sobre a História do Governo e da Legislação em Portugal, Coimbra, 1872, Imprensa da Universidade, p. 99-100)

Se praticamente emudecidos ou vacilantes nas primeiras reuniões, os representantes dos concelhos acabam marcando notadamente suas presenças e sabem transferir a preocupação daqueles dos quais são mandatários, ouvindo-lhes o rei suas queixas e reclamos, para melhor administrar e conduzir os destinos de seu governo. Seria extremamente temerário ensejar comparações com o sistema parlamentar dos séculos posteriores ou da atualidade, pois cada instituição há de ser vista com a textura que lha fornece a época em que vigiu; não se pode desmerecer, entretanto, o significado integrativo das cortes na estrutura daqueles reinos, mesmo que os votos apostos pelos seus membros, pudessem sofrer, por vezes, as naturais limitações, restrições ou adaptações da ação real.

5. Até a introdução do Direito Romano em Portugal, o processo caminhava lado a lado com outros modos mais rudes de solução dos litígios, tudo isto significando o resultado da carga germânica que ainda subsistia entre os habitantes das aldeias e povoados, segundo se pode observar pela simples leitura dos forais mais antigos. No que diz respeito aos recursos, como forma de acesso à Coroa, com vista à reforma da decisão, eram completamente inviabilizados ou se revestiam de caráter extraordinário e excepcional.

A querima ou querimônia, meio do qual dispunham os comunheiros para se insurgir contra as sentenças dos senhores ou juízes da terra, era proibida em vários diplomas foraleiros, assim se expressando, v.g., o foral de Évora, de 1166 : 
"Et si cum querimonia de ipso ad regem vel ad dominum terre venerit, pectet $C$ morabitinos medietatem regi et medietatem concilio" (Portugalia Monumenta Historia, Leges, I, p. 393)

Com pequenas variantes, relativas ao beneficiário da multa, encontramos repetida a frase nos forais de Abrantes, 1179, (p. M.H., Leges, I, p. 419) Palmela, 1185, (p. 430) Penamacor, 1209, (p. 581) Alcazar, 1218, (p. 609) Idanha, a Velha, 1229, (p. 614) Aljustrel, 1252, (p. 637) Aroche, 1255, (p. 1.252) Alcáçovar, 1.258, “ad episcopum..." (p. 690) Tolosa, 1262, "priori et conventu”, (p. 702) Gravão, cerca de 1267, “ordini", (p. 709) Seda, 1271, "magistro" (p. 421)

Mais severo, ainda, o foral de Vila Boa, de 1216: "et toto vicino de Villa Bona que fuerit cum querimonia de suo vicino a rege etgnon quesierit accipere iudicium de vestros iuratos, pectet $X$ morabitinos et exeat de villa et remaneat hereditate in manu de vestro concilio" Além de pagar a multa, o ousado vizinho acabaria expulso da vila, com perdimento de todos os seus bens... (P.M.H., p. 569)

No estudo dos forais dessa época, importa observar: primeiro, a inexistência das palavras apelar ou apelação em tais documentos, em Portugal; e, em segundo lugar, a persistência em se impedir o uso da querima durante a segunda metade do século XIII, isto é, no mesmo período em que D. Afonso III introduz a apelação na ordem jurídica do reino. Por aí se vê que não é possível dizer que a apelação era costume em Portugal, como afirma a lei introdutória de D. Afonso III. Por outro lado, a queixa, querima ou querimônia, trazia um significado impreciso, vago, "exprimindo antes imploração do que propriamente recurso" (Alfredo Buzaid, Do agravo de petição no sistema do Código de Processo Civil, S. Paulo, 1956, Saraiva, p. 45)

Em alguns fueros ibéricos, vamos encontrar a possibilidade de apelar ou alçar-se ao rei. Mas esta modalidade de recurso apresenta características próprias, peculiares a esse período anterior, distintas daquele no qual se adotarão institutos de ascendência direta romana. Niceto Alcalá Zamora y Castillo compara o seu procedimento à autêntica novela de aventuras; (Instituciones Judiciales y Procesales delfuero de Cuenca, in Estudios de Teoria General e Historia del Proceso, Mexico, 1974, Universidad Autonoma de Mexico, p. 396) e, com efeito, é o próprio foral de Cuenca que nos mostra a precariedade da via eleita, mormente quando se considera que as partes deveriam caminhar por terras inóspitas, sujeitas às cavalgadas e razias, fosse do mouro perseverante, fosse dos nobres em periódicas quesilhas, quando não estivessem sujeitas, também, às acometidas de malfeitores expulsos da vilas e 
aldeias. Anotem-se os termos do recurso: Capítulo XXVIII: "Los que apelen al rey: El juez dá a los apelantes como fiel un andador cualquiera. (1) Designado el fiel, si alguno de los litigantes no se atreve a ir publicamente por miedo a sus enemigos, jure que es verdad que tiene enemigos y vaya al Rey por donde le plazca. (5) "El que llegue primero al Rey espere a su contrario tres dias...si no sabian el lugar exacto...seis dias. (6) Si uno hiere, mata o incluso si injuria en el camino a su adversario, pague doble la pena del delito que haya cometido. (9) Si muere el fiel, los litigantes regresen y el juez designeles otro fiel. (10) Si a los litigantes les resulta pesado el viage y quieren designar a otro en lugar del Rey para que los juzgue..." (11) (El Fuero de Cuenca, introdução, tradução e notas de Alfredo Valmanã Vicente, Cuenca, 1978, Ed. Torno, p. 207 e ss.)

Estas disposições repetem-se, com variantes, em outros fueros, como, por exemplo, no de Úbeda, Tít. VI, De las alçadas e como se an de seguir, (Fuero de Úbeda, Mariano Peset, Juan Gutierrez Cuadrado e Josep Trenchs Odena, Valencia, 1979, Universidad de Valencia, p. 358) e nos "fueros municipales de Cáceres" onde vem prevista a possibilidade de as partes se alçarem ao rei, se a causa for de valor superior a dez morabitinos, exigência que se encontra, também, nos diplomas antes mencionados. (Los fueros municipales de Caceres, Caceres, 1974, p. 309) Da mesma forma, o Fuero, de Beja admite alçar a rey nas causas superiores a dez mencales, ns. 817 e seguintes. (Fuero de Bejar, Juan Gutierrez Cuadrado, Alamanca, 1975, Universidad de Salamanca, p. 146)

Nos costumes e foros de Castel Rodrigo e Castelo Melhor, de 1209, encontramos o título qui por seu juyzio se queser alçar, sendo estabelecidos algumas disposições semelhantes aos fueros aludidos, a respeito das partes que pretendessem recorrer ao rei. (P.M.H., Leges, I, p. 875 e 920) Acontece que tais foros foram concedidos por Afonso IX, de Leão, pois a esse tempo, ditas vilas pertenciam a esse reino e não a Portugal; somente no fim do século XIII é que elas passariam a se integrar ao território lusitano. Assim, ainda que entre os fueros de Castela e Leão e os forais de Portugal se denote, muitas vezes, a influência de uns sobre outros, verifica-se que no caso desse tipo de recurso, tais concessões não passariam ao reino luso, já que os diplomas ou silenciam a respeito ou proíbem expressamente qualquer meio de acesso ao rei.

De qualquer maneira, mais uma vez somos levados a concluir que as eventuais reclamações, restritas às querimas, nada tinham a ver com a apelação, na 
forma como se introduzirá e virá descrita na lei de D. Afonso III. (a respeito, p. 74-6 e notas 27 e 28 da Origem e Introdução..., cit.)

6. Passando agora ao exame da lei em apreço: Nas notas introdutórias ao parágrafo $3^{\circ}$ das Leges e Consuetudines dos Portugalia Monumenta Historica, que tratam das Leis Gerais, Alexandre Herculano, depois de se demorar no Livro das Leis e Posturas, (códice em fólio, escrito em pergaminho e em duas colunas, caracteres assentados do princípio do século XV. senão dos fins do XIV) refere-se a outros códices: o primeiro, designado pelo título "Foros de Santarém"; (maço $3^{\circ}$ (n. 2) de Foraes Antigos do Arquivo Nacional da Torre do Tombo), o segundo, conhecido como "Foros da Guarda"; (maço $6^{\circ}$ (n. 4) de Foraes Antigos) e o terceiro, como os "Foros de Gravão"; (maço 11 $1^{\circ}$ (n.11) de Foraes Antigos), além destes, os "Foros de Beja" (maço $10^{\circ}$ (n. 7) de Foraes Antigos. Os foros de Santarém, Guarda e Beja, acima mencionados, ao se referirem às leis passadas ao tempo de D. Afonso III, trazem respectivamente, as seguintes rubricas: "Aqui sse começam as posturas que foram feitas em Coimbra e em lixbõaa e en Leirea de novo por prol de todo o Reyno por aquelles do Conselho dEL Rey" (Santarém) "Estas sum as pusturas as quais forom feytas en Coynbra e en leyrea e en Lisboa pera prol de todo o Reyno" (Guarda) "E estas mandou guardar elrey dom Affonso o terceiro, feytas em Coymbra e em leyrea" (Beja)

Os foros da Guarda, ao tempo da publicação dos Portugalia, já haviam sido levados à estampa na Coleção de Inéditos da História Portuguesa, da Academia Real de Ciências de Lisboa, volume V, editado em 1824. Nessa publicação, tanto consta a rubrica supratranscrita, como a lei que cuida da introdução da apelação em Portugal, e que está no Livro das Leis e Posturas, nas fls. 27, verso, $2^{\mathrm{a}}$ coluna. (p. 95 da edição impressa, de 1971) E nos Portugalia, Leges, na p. 247, com as variantes que ali se assinalam. (Coleção cit., p. 436 e 446)

Deparamos, assim, com três documentos antigos, (Santarém, Guarda e Beja) nos quais se diz, expressamente, que as posturas, (entre as quais, a que introduz a apelação) foram feitas por ocasião das cortes celebradas nas cidades de Leiria, (1254) Coimbra, (1261) ou ainda, não em cortes, mas na cidade de Lisboa, para onde estão sendo transferida progressivamente a administração do reino.

Sobre tais códices, acrescenta Herculano "Que são estas diversas leis e posturas que nos três códices de Santarém, da Guarda e de Beja se dizem feitas em Coimbra e em Leiria? Evidentemente, são providências tomadas nas cortes de Leiria, de 1254 e nas de Coimbra, de I261, ou para melhor dizer, em conseqüencia 
das representações dos povos apresentadas naquelas assembléias. " (P.M.H., Leges, I, p. 155-6)

$\mathrm{Na}$ obra já referida sobre as Cortes de Leiria, de 1254, Marcello Caetano rejeita essa conclusão, asseverando que não há prova plena de que nessa assembléia tenham sido elaboradas e solenemente promulgadas algumas leis gerais; e ao se referir às leis constantes daqueles códices existentes no Arquivo Nacional de Torre do Tombo, acrescenta: "De que tratam essas leis gerais? Quase todas do processo judicial e do processo a seguir na Corte de el-rei. Quer dizer que não estamos perante matéria que seria natural constituísse objeto de artigo de agravamento do clero, dos nobres ou dos concelhos, nem a forma das leis deixa adivinhar que estas tivesse começado por ser respostas dadas em Cortes. A fazer fé pelas rubricas dos códices dos foros, teremos que aceitar também o que diz o de Santarém e deve ser exato: que tais leis foram feitas por legistas do Conselho Régio, não em Cortes..." "Até que surjam novos elementos que justifiquem tal opinião, entendemos que se algumas leis gerais foram elaboradas em Leiria, nos meses de fevereiro e março de 1254, foi por trabalho dos legistas e não por diligência e com o concurso dos representantes dos conselhos." (ob. cit., p. 42-3)

Rigoroso quanto à participação nas Cortes de Leiria, o saudoso professor reconhece, no entanto, que nas Cortes de Coimbra, que se lhas seguiram, não desempenharam eles o papel de simples mensageiros, de portadores de súplicas a submeter à despacho régio, mas de "membros de uma assembléia que reivindica direitos e que intervém na definição das regras a incluir na lei" ("Subsídios...", cit., p. 143)

7. Examinados todos estes aspectos, em especial este último confronto colocado em torno da matéria por dois baluartes da ciência histórica em Portugal, cabe-nos oferecer as ponderações que seguem e que têm por propósito complementar o estudo por nós realizado, em 1976, sobre a origem e a introdução da apelação no Direito lusitano:

I. Costume e lei não se confundem. Na Idade Média, no entanto, estes conceitos comportam ambigüidade, quando se considera que, muitas vezes, antigos costumes recebem o respaldo real, passando à categoria de lei; além disto, no afã legislativo que se desenvolve a partir da recepção do Direito Romano, os costumes sofrem acentuada revisão, pelo que acabam sendo modificados ou substituídos por outras disposições, emanadas, sempre, da vontade régia. 
II. Neste trabalho constante, do qual o monarca se incumbe, vale-se ele do concurso de letrados, conselheiros, legistas. E vai encontrar suporte, também, na voz que provém das cortes, as quais com frequiência se reúnem, para que nelas se discutam e se resolvam os problemas de maior relevância que preocupam todo o reino.

III. a participação popular nas cortes, a princípios débil, gradativamente se reforça, a tal ponto que, com o tempo, muitas das leis promulgadas são o resultado das queixas e reclamações oriundas dos estamentos sociais que as compõem, entre elas se incluindo aquelas trazidas pelos representantes dos concelhos e dos povos.

IV Antes da recepção do Direito Romano, a forma pela qual os súditos do reino ofereciam suas queixas contra os agravos recebidos pelos senhores locais ou juizes da terra, eram as querimas ou querimônias, as quais guardavam traços de manifesta ascendência germânica; e isto era natural, de vez que inseridas no direito costumeiro e tradicional, até então vigente.

$\mathrm{V}$ Este remédio, todavia, esbarrava nas contingências próprias do tempo e do lugar em que se empregava, constituindo meio de caráter excepcional, quando não expressamente vedado pelas regras foraleiras.

VI. A lei de D. Afonso III veio alterar completamente o quadro anterior; não quer isto dizer que as suas diposições passaram a ser obedecidas desde logo, pois conheceriam elas todos os entraves decorrentes do momento em que eram editadas: resistência dos membros mais elevados da população, notadamente dos senhorios locais; dificuldade que existia para que fossem conhecidas em todos os limites do reino; afirmação ainda precária do comando legal sobre a ancianidade dos costumes e sobre o espírito comum ao medievo, tão refratário à modificações que nem sempre inspiravam confiança ou fé...

Daí porque o rei, utilizando-se de expediente comum à época, pretende dar à lei o matiz de costume longamente usado, quando isto, em verdade, não acontecia. E daí a provável razão para as variantes encontradas, as quais tanto podem resultar de divergência entre copistas, quanto da insistência com que ele pretende impor a sua ordem "ca tal he e quero que seia custume do meu Reino"

D. Diniz, ao sucedê-lo, prossegue no intuito de que as justiças usem de seu ofício, de tal modo que os recursos venham ter ao rei e a ninguém mais. (Lei de 1282, L.L.P., fls. 13, v, $1^{a}$ col., p. 50) Embora esta lei afirme que ao tempo de seu pai e de seus antecessores, já se apelava, verifica-se que aqui se repete o igual 
propósito de dar longevidade ao instituto, pois a apelação havia surgido com D. Afonso III, e não antes. Afonso Henriques, Sancho I e Sancho II, praticamente não legislaram e ainda menos sobre essa matéria, ocupados que estavam em expandir os seus domínios; quanto a Afonso II, ainda que em uma das primeiras leis gerais então editadas, pretenda estabelecer juízes seus em todo o reino, (Lei de 1211, L.L.P., fls. $1,1^{a}$ col., p. 9) certo é que não alcançará desde logo este desígnio, diante da resistência que encontra nos senhorios e nos próprios concelhos.

VII. A lei que introduz a apelação em Portugual, como já se fez referência, é aquela constante da página 95 da edição impressa do Livro das Leis e Posturas. Existem várias disposições que tratam desse recurso no mesmo exemplar, entre elas o excerto de um tratado de processo que se encontra em páginas anteriores; mas não é deste tratado, e sim daquela lei que sempre cuidamos de examinar e continuamos examinando.

VIII. Perquirindo com mais vagar as conclusões de Alexandre Herculano e Marcello Caetano, temos de convir que não são elas tão discordantes assim: pois o primeiro considera que as leis feitas em Leiria e Coimbra são providências tomadas em conseqüência da representação dos povos apresentadas naquelas assembléias; enquanto o segundo, embora divirja, admite que em Coimbra, tais representantes não eram simples mensageiros, mas ali estavam para reivindicar direitos, buscando incluí-los nas leis que estavam para ser promulgadas.

IX. Se está armado nas cortes "o espírito da comunidade política, com interesses coletivos próprios a defender perante o poder real", (Marcello Caetano, Cortes de Leiria, cit., p. 48) que melhor resposta poderia ofertar o rei a seu povo senão outorgar uma lei que admitisse, sob moldes modernos e objetivos, um direito que se apresentava até então reduzido, ou mesmo proibido? O direito, enfim, de apelar sem peias para o rei ou para os seus juízes?

X. A introdução da apelação no Direito lusitano ocorre com a edição da lei de D. Afonso III. Quando, exatamente, dimanou do selo real, os documentos silenciam. Mas é certo que se deu entre 1254, e destes dez anos para a frente, pois os manuscritos repetem: Leiria, Coimbra, Lisboa, sendo esta última cidade o local para onde D.Afonso vai transferindo em caráter permanente a sede de seu reino.

XI. Não há, também, provas concretas de que a lei tenha resultado diretamente das queixas formuladas pelos povos. É mais provável tenha partido da iniciativa dos legistas da Corte, que muitas as elaboraram nesse período, imprimindo nelas o crivo do Direito justinianeu. 
Não se pode desprezar, contudo, o influxo provocado pelos homens bons, que pretendiam melhor ver assegurados os seus direitos; esta prática é comum nas cortes dos Reinos Ibéricos, desde épocas anteriores ao reinado de D. Afonso III, e era lógico passasse também a Portugal.

Ora, a estes homens deveria inquietá-los e, muitos, a impossibilidade ou dificuldade de se insurgirem contra a justiça dos senhores ou juízes da terra; por isso, tinham interesse lhes fosse concedido o direito de livremente expressarem suas queixas contra os gravames recebidos e sofridos.

Direito este que, como se viu, acaba se traduzindo num recurso inédito, que se ajusta a um tempo novo e a uma nova visão da política administrativa e jurisdicional. Este recurso, é a apelação. 